\title{
The History of Jehovah's Witnesses in Hungary
}

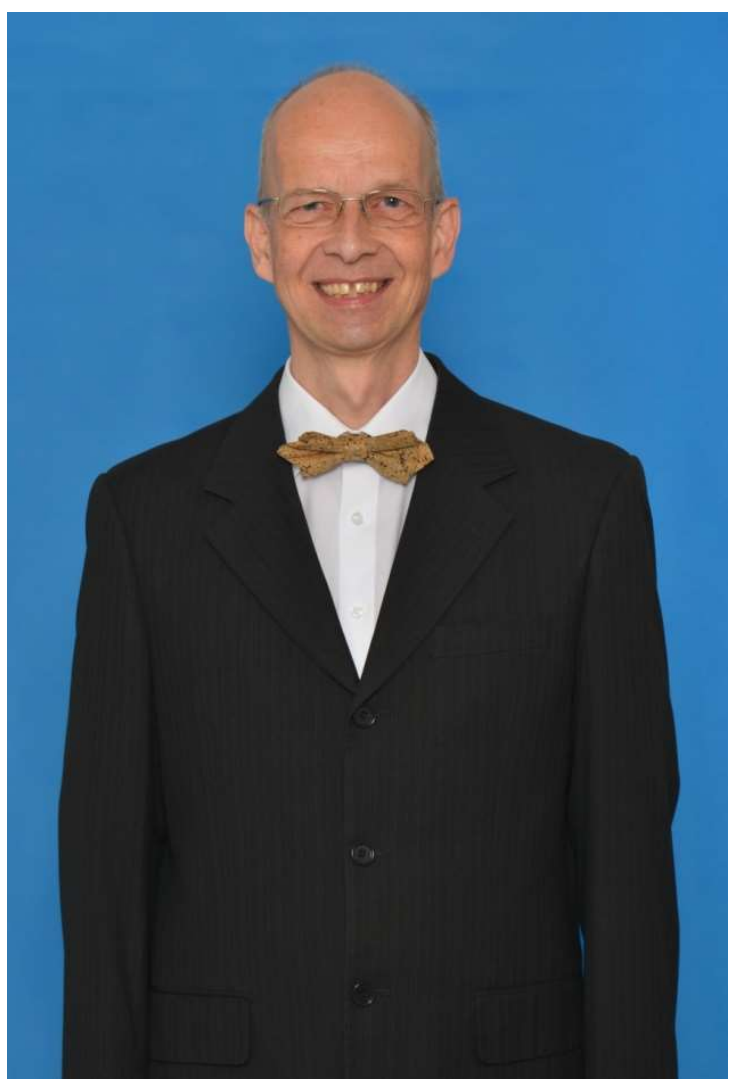

\begin{abstract}
Andy Besuden is born in Germany in 1961, he received most of his schooling in Vienna, Austria, where he graduated with a Master's degree in Business Administration in 1986. Originally born into a family of Lutheran beliefs, he started to study the Bible with Jehovah's Witnesses in 1970. Baptized in 1981, he started full-time volunteering as Jehovah's Witness in 1987. After receiving special training, he was sent to Hungary in 1992 to help organizing the preaching work that had been granted legal recognition three years before. Among other assignments, he helped with researching the history of Jehovah's Witnesses in Hungary. At present, Andy Besuden is serving as missionary in Szeged.
\end{abstract}

Tudor Petcu: First of all, please let us know which would be the main aspects concerning the history of Jehovah's Witnesses in Hungary that we should know. When did the first Jehovah's Witnesses appear in Hungary?

Andy Besuden: Zion's Watch Tower (issue of May 15, 1898) had published the following announcement about a brother [a Bible Student, as Jehovah's Witnesses were then called] in Canada: "We bid Goodbye to a dear brother who starts for his native land, Hungary, to tell the good tidings to his countrymen. A professor for years in the schools of his native land, he is well educated in Latin and German as well as Hungarian, and we trust that he may be used of the Lord to find and to seal some of the elect."

The 1996 Yearbook of Jehovah's Witnesses on page 68 continues about the professor: "His activity evidently yielded results. Five years later, when Charles Taze Russell and his traveling companions visited Zurich, they met, among others, two fellow believers from Hungary. In addition, several letters from Hungarian brothers published in the German edition of Zion's Watch Tower in 1905 show that some were receiving Bible literature by way of Germany."

"In 1908, Andrásné Benedek - a humble Hungarian woman who had become a Bible Student, as Jehovah's Witnesses were then known - returned to Hajdúböszörmény, in eastern Hungary, to share with others the good news that she had learned from God's Word. Four years later, two more Bible Students returned from the United States. They had learned the truth about 
God and his purposes by attending some of Brother Russell's public discourses. Brother Russell made it a practice, after such programs, to approach those in the audience whom he had seen attend several times before. He would ask: "Where are you from? What is your nationality? Would you like to return to your relatives and share the truth with them?"”

"One of these two Bible Students, Károly Szabó, returned to the town of Marosvásárhely (now Tîrgu-Mureş, Romania), which was then in Hungary. The other brother, József Kiss, worked with Brother Szabó distributing literature in that vicinity before returning to his own hometown, Abara (now Oborín, Slovakia). Their activity brought results, for Brother Szabó's family accepted the truth, and later more people in that area took their stand for the truth and joined in preaching the good news."

Tudor Petcu: Given the purpose of our dialogue, I would appreciate it very much, if you could highlight in a relevant way the reasons why the Jehovah's Witnesses endured so many sufferings in Hungary during their history. Why were they targeted by the different Hungarian regimes?

Andy Besuden: Jehovah's Witnesses were persecuted all over the world, not only in Hungary. The book Jehovah's Witnesses - Proclaimers of God's Kingdom states on page 675:

"Canada and the United States led off the attack by imposing bans on Bible literature during the First World War, and they were soon joined by India and Nyasaland (now called Malawi). During the 1920's, arbitrary restrictions were imposed on the Bible Students in Greece, Hungary, Italy, Romania, and Spain. In some of these places, distribution of Bible literature was forbidden; at times, even private meetings were prohibited. More countries joined in the assault during the 1930's, when bans (some on Jehovah's Witnesses, others on their literature) were imposed in Albania, Austria, Bulgaria, Estonia, Latvia, Lithuania, Poland, certain cantons of Switzerland, what was then Yugoslavia, the Gold Coast (now Ghana), French territories in Africa, Trinidad, and Fiji."

"During World War II, there were bans on Jehovah's Witnesses, their public ministry, and their Bible literature in many parts of the world. This was true not only in Germany, Italy, and Japan - all of which were under dictatorial rule - but also in the many lands that came directly or indirectly under their control before or during that war. Included among these were Albania, Austria, Belgium, Czechoslovakia, Korea, the Netherlands, Netherlands East Indies (now Indonesia), and Norway. During those war years, Argentina, Brazil, Finland, France, and Hungary all issued official decrees against Jehovah's Witnesses or their activity."

What was the reason for this global persecution? The Watchtower of December 1, 1998, states: "Basically, Jehovah's Witnesses have been unjustly hated for the same reasons that the early Christians were persecuted. First, Jehovah's Witnesses act upon their religious beliefs in ways that make them unpopular with some. For example, they zealously preach the good news of God's Kingdom, but people often misunderstand their zeal, viewing their preaching as "aggressive proselytizing." (Compare Acts 4:19, 20.) They also are neutral toward the politics and wars of the nations, and sometimes this has been wrongly taken to mean that the Witnesses are disloyal citizens - Micah 4:3, 4."

"Second, Jehovah's Witnesses have been targets of false accusations - barefaced lies and twisted presentations of their beliefs. As a result, they have been the object of unjustified attack in some lands."

Time and again, leaders of established religions, which cooperate with state institutions, were and are behind the persecution of Jehovah's Witnesses. This contributes to the fact that even when regimes (together with the ideologies behind them) changed, the hostile attitude towards the Witnesses remained.

Tudor Petcu: I would be interested to find out some more information especially about the sufferings of Jehovah's Witnesses during Horty Miklos' dictatorship and also during the communist regime. So, please explain to us how affected Hungarian communism the Jehovah's Witnesses from 
a social point of view and when I am asking you that I especially make reference to the Hungarian communist prisons where Jehovah's Witnesses were tortured and persecuted.

Andy Besuden: During the 1920's several Hungarians returned to their home country in order to proclaim the Bible truth they had embraced in the United States. In general, they did not preach in larger cities, but in the villages of their origin and in surrounding areas. Some could even establish congregations consisting of 30 to 40 members.

At first, the state did not care about this kind of activity. Without being hindered the Bible Students could distribute publications, which had either been printed in Cluj or had been sent in from Germany and the United States. Initially, the church did not consider them dangerous, thinking that they are only a few sectarians who ensnare those of weak character or those in dire straits. However, when the Bible Students grew in number, the concerns of the 'accepted' churches - Catholic, Reformed, Evangelical - grew in proportion. In one parish, the priest openly acknowledged that the Bible students are successful because the Church does not deal sufficiently with the spiritual needs of their faithful, they neither shepherd nor evangelize adequately. Furthermore, most villagers and farmers lived in poverty. According to the Church leaders, these two reasons made the lower class accept the promising teachings of the "sectarians."

With the goal to counter the spread of sectarianism, in some places the priests made real efforts to improve the spiritual condition of their parishioners and to intensify pastoral care. They held night masses and visited families, which produced some results.

The 'accepted' churches cooperated closely with the state. Hence, most parishes, which, instead of practicing self-criticism, were dismayed as ever more of their flock joined the "sectarians", could turn to the state to stop the sect of Bible Students (or Millennialists) by force. This resulted in house searches, arrests and imprisonments. The violent exercise of governmental power lead directly to the ban of the Bible Students' publications (books, flyers, tracts). The charge was more or less "incitement against the accepted churches and their clergy". "Incitement" remained the primary accusation until the ban of 1939. Media reports suggested that the Bible students are a political movement in a religious disguise, which turns against churches that are an institutional part of society and politics. Especially the Reformed Church demanded state intervention, while it did not make any efforts to regain its lost sheep.

As the Bible Students came under state monitoring, the government also found fault with their message. In their publications and preaching activity the Bible Students discouraged their brothers from fighting, from the use of arms and from participation in or support of wars. Hence, the charge was extended by claiming that the sect spread antimilitary propaganda.

The Treaty of Trianon (article XXXIII, paragraph 55) guaranteed freedom of religious observance, however, the authorities bypassed the treaty by applying the general rules of assembly to sects. This resulted in even tighter monitoring and by 1939, when Jehovah's Witnesses were banned, in outspoken persecution.

The charges against the Bible Students - from 1931 onwards known as Jehovah's Witnesses - were continuously extended. After being accused of incitement against the accepted churches and their clergy and of antimilitary propaganda, now they were labeled as communists. The basis for this was the Bible teaching, which the Witnesses proclaimed, that human governments, borders and inequalities would discontinue. The then authorities identified these as obvious principles of communism. The Witnesses reasoned and showed publications, which explained the Bible's stand against communism - to no avail: without any proof the authorities stuck to their accusation. The charge of being Zionists also remained for some while.

After 1933, the situation became ever serious. Jehovah's Witnesses were viewed as agitators of communism, who were directed by Moscow through America and Prague. This leads too many imprisonments, as society then considered communism to be the most dangerous enemy. House searches, observation and harassment by the police and gendarmerie, imprisonments and court convictions were the daily bread of the Witnesses. Prison sentences were later replaced by internment camp sentences, and whoever did not join the army was sentenced by court-martial. In 
March 1937, a countrywide investigation was launched leading to mass imprisonments until June of that year. The authorities' goal was the liquidation of Jehovah's Witnesses as community.

In December 1939, the Interior Minister banned by decree numerous churches, or "sectarian movements". As the war approached, the political authorities obviously perceived the refusal of taking arms as increasingly dangerous. At the same time, the Belügyi Közlöny (Ministry of the Interior's Gazette) of December 17, 1939, stated that they do not want to protect only the lawful order of state and society, as well as the institutions of the army and national defense, but also the interests of the historical, recognized churches. Thus, it was plain to see that state and church cooperated closely.

After the Kingdom of Hungary had entered World War II in June 1941, the refusal of taking arms was condemned more strongly with more serious consequences. It was classified as "subversion of the lawful order of state and society". Arrested Witnesses were often beaten, tormented, and women were raped during interrogation. They were tried in camera and severely sentenced on the spot.

The State Security Centre (ÁVK), founded in June 1942, acted vigorouslyagainst the Witnesses. Within two months many were imprisoned. After serving their prison sentence the Witnesses were automatically delivered to internment camps. They had to endure ever more brutal treatment and longer sentences. Some were even executed.

In labor camps like Kistarcsa, Nagykanizsa and Bor the Witnesses always stuck together, did not rebel, and did not try to escape. This attitude won the respect and trust even of the Hungarian guards, who as a result tempered their way of dealing with them.

From 1945 to 1948, the Witnesses enjoyed freedom. As soon as possible they had their publications legalized, which they could use freely during their preaching activity. The term "sect" disappeared from legislation, and even the press published articles in a positive tone. However, the negative reputation from the Horthy era was still alive in people, many of whom continued to view the Witnesses as sectarians. As the Witnesses grew in number, they held large public meetings.

By 1948, it became clear that Hungary would follow the example of the Soviet system, hence state dealings with churches would change as well. 1949 was a turning point for Jehovah's Witnesses, from then on they were portrayed as agents of American imperialism. In this environment the refusal of taking arms was viewed as betrayal of socialism or "harmful pacifism". Many Witnesses were imprisoned. Again, state bodies and the press called the Witnesses a sect.

The ultimate goal of the state was to create the exclusive rule of atheist ideology, to which all religious communities seemed to be an obstacle. Each political system produced bogeymen, the Witnesses were always considered as such. During four decades of state socialism the Witnesses were defined as friends of America, imperialists, who distribute the "opium" called religion, and as enemies of the political system. The regime looked for a scapegoat for their own mistakes, which they found in Jehovah's Witnesses.

Meanwhile the large historic churches increasingly viewed small churches and religious communities, including the Witnesses, as their enemies. Hence state and large churches were close allies in their actions against the Witnesses. The communist regime successfully misused the large churches' tradition of theological and ideological attacks against small churches, a leftover from the Horthy era.

In 1949, the principle of separation of church and state were enshrined in the constitution, however, the legal state of small churches was not fully clarified. Still in force was a law from 1895, according to which a religious community could be refused legal recognition, if its deeds violated the interests of any legally recognized church.

The Witnesses did not join the alliance of churches, which is why they were not supervised by the ÁEH (State Office for Church Affairs), but by the Ministry of the Interior based on the law of assembly. In Autumn of 1952, the distribution of the Witnesses' publications was banned, and it was ordered that the existing copies should be confiscated and destroyed.

From 1950 onwards, Jehovah's Witnesses were persecuted in the GDR, from 1951 onwards also in the Soviet Union, Poland, Lithuania, Estonia and Moldavia. They were trialed and deported. 
In 1950, the Hungarian brothers in responsible positions were imprisoned and received sentences of many years for inflammatory activities against the regime. Altogether 302 Witnesses were imprisoned that year.

Under the Rákosi regime those refusing to take arms and partaking in illegal religious activities were sent to internment and labor camps, many for 8 to 10 years. Actually, the labor camps were mines, where the Witnesses had to work hard under dangerous conditions. They endured with dignity: they enjoyed being together and organizing congregational meetings. During the amnesty of 1953 not one Witness was set free.

By the late 1950s, it became clear that through persecution the organization of Jehovah's Witnesses cannot be liquidated. This was acknowledged, for example, by the Soviet KGB conference in 1959. They decided on a new strategy, namely the combination of oppressive and subversive measures. As in Hungary similar experiences were made, the state changed tactics during the early 1960s by using subversive measures against Jehovah's Witnesses. In Spring 1961, for example, they imprisoned János Konrád, searched his home and confiscated his literature. Right afterwards other brothers were imprisoned, after their homes had been searched, as if Konrád had revealed names and addresses, which in reality they had already known of. They had a schedule of whom to imprison and whom to release at what time. These cases were not taken to court. The goal was to sow uncertainty and create an atmosphere of distrust among the brothers.

On the basis of the 1960 Defense Act, conscientious objectors continued to be sentenced. Military courts sentenced Witnesses, who refused to take arms, to one to five years imprisonment. Faith could be practiced only at home, and meetings could be held only in forests.

The subversive concept was also unsuccessful, hence in 1964 the Ministry of the Interior and the ÁEH (State Office for Church Affairs) mapped out another strategy against the Witnesses: "One of the best methods of repression is to influence certain sects and their leaders with the prospect of legalization." In 1965, they encouraged János Konrád to draft statutes, which would be acceptable for Jehovah's Witnesses, if legalized. Konrád drafted two versions, however, likely due to two facts legalization could not be accomplished. First, the Witnesses were not willing to disclose the names of responsible brothers, the addresses of certain operations and congregational meetings, as well as the continuous updates of all these. Second, the state was not willing to accept the unchanging position of the Witnesses concerning conscientious objection. Thus, the Witnesses remained illegal, nevertheless they continued to operate with the knowledge of state institutions.

From the late 1960s onwards, tools of secret services, like interception, were increasingly applied to control the Witnesses. For the collection and preparation of incriminating material the acknowledged churches were also engaged.

In 1971, the ÁEH (State Office for Church Affairs) made efforts to provide an unarmed military service for conscientious objectors. Instead of taking an oath they would have to make a declaration. Finally, the Nazarenes made use of this possibility (which went into effect on February 1, 1977), however, the Witnesses' point of view did not change on this matter.

In the 1970s, administrative measures against the Witnesses like those in the 1960s were not taken anymore, only identity checks and warning conversations were applied by the police to those who preached from house to house. Plainclothes policemen, who disturbed the forest meetings, did not raise objections against the meeting itself, but expressed environmental concerns.

In the 1980s, conscientious objection was still a problem between state authorities and the Witnesses who continued to endure three-year prison terms. As prisoners, they were reliable and their conduct was exemplary, working hard and with dignity. After having served their term they were not drafted again.

In those years, circumstances improved rapidly for the Witnesses. In 1985, the Minister of the Interior gave permission to hold conventions in forests and on private property, 1200 persons were even allowed to attend conventions in Vienna, Austria.

In 1984, the Witnesses contacted the ÁEH and continuous negotiations were initiated, during which they were represented by local brothers and some from World Headquarters. As final result, on June 27, 1989, Jehovah's Witnesses were legally recognized by the Hungarian state. For 
the State Office for Church Affairs, this was the last action of that kind that it took. It was closed down four days later, on July 1, 1989.

Tudor Petcu: Is there in Hungary any relevant book about the sufferings of Jehovah's Witnesses that has been written and if so, please describe it to us in some words and tell us where can we find it?

Andy Besuden: 1996 Yearbook of Jehovah's Witnesses, pp. 66-115 (available also in Romanian); A Magyarországi Jehova Tanúi Egyház története - a kezdetektöl napjainkig [The History of Jehovah's Witnesses in Hungary - From the Beginnings up to Now], 2017, Budapest: Fazekas Csaba, Jakab Attila, Petrás Éva, Szita Szabolcs (available only in Hungarian); Ti vagytok az én tanúim... [You are my witnesses...], Martinkó Károly (editor), Budapest (available only in Hungarian).

Tudor Petcu: Who are the most important representatives of Jehovah's Witnesses that have been suffering in the communist Hungary? Where can we find some testimonies about their sorrows?

Andy Besuden: On several occasions, especially in the 1950s, the Communist regime imprisoned those who took the lead among Jehovah's Witnesses. Among them were János Konrád, András Bartha, János Lakó (still alive), Zoltán Hubicsák, György Podlovics and Sándor Völgyes. In the 1996 Yearbook of Jehovah's Witnesses the Communist era is described on pages 96 to 110. Details can be found in the archives of Jehovah's Witnesses in Budapest and in the books mentioned above (under question 4.).

Tudor Petcu: Taking into account the times in which we are living, what would be your main spiritual testimony and message as a representative of Jehovah's Witnesses for the contemporary Hungarian society? Not least, I would be very tempted to ask you how should we read the Bible and understand Jehovah's Kingdom in the contemporary era, dominated by the values of social pragmatism.

Andy Besuden: As no human government has been and will ever be able to solve the big problems of mankind, people need to know the solution proclaimed by their Creator. Therefore, Jehovah's Witnesses preach the Kingdom message worldwide (Matthew 24:14), which is a basis for a happier life already now and for future blessings that only God can achieve: everlasting life without diseases, peace among humans as well as between humans and animals, no more natural disasters, etc.

To get in line with their Creator, people need to know what He requires from them as outlined in the Bible. For this reason, Jehovah's Witnesses in Hungary - as everywhere else in the world - offer a Bible study free of charge to everybody. In this way, they share with their fellows the results of more than 140 years of concerted Bible study (Acts 8:26-31).

For the past millenniums, the message of the Bible and its meaning has not changed. It is independent from any political, social or religious interpretation. Practical suggestions for how to read the Bible are offered, for example, in the no. 12017 issue of The Watchtower (available also in Romanian).

Above all, we should never forget that although some 40 humans penned the Bible, its author is Jehovah God himself. Hence, we let the Bible interpret itself (Genesis 40:8) and not by relying on human philosophy or wisdom. A good example for this is God's Kingdom, a realistic discussion of which one can find in the book God's Kingdom Rules!, published in 2014 by Jehovah's Witnesses (available also in Romanian). 